\title{
Sistem Kendali dan Monitoring pada Smart Home Berbasis Internet of Things (IoT)
}

\author{
Ruuhwan ${ }^{1}$, Randi Rizal ${ }^{2}$, Indra Karyana ${ }^{3}$ \\ ${ }^{1,2,3}$ Teknik Informatika, Fakultas Teknik, Universitas Perjuangan, Jalan PETA No. 177 Tasikmalaya \\ ${ }^{I}$ ruuhwan@unper.ac.id, ${ }^{2}$ randirizal@unper.ac.id, ${ }^{3}$ indra@gmail.com
}

INFORMASI ARTIKEL

Sejarah Artikel:

Diterima Redaksi:28 Agustus 2019

Revisi Akhir: 01 Oktober 2019

Diterbitkan Online: 4 Oktober 2019

\begin{tabular}{l} 
KATA KUNCI \\
\hline Internet of Things, \\
Arduino, \\
Android, \\
Teleduino, \\
Smart Home \\
KORESPONDENSI \\
\hline
\end{tabular}

No. HP : +62 85320132014

E-mail : randirizal@unper.ac.id

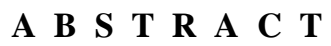

The Smart Home system consists of control, monitoring and automation devices that can be accessed from anywhere as long as there is an internet connection. In Smart Home, several devices or home appliances that can be accessed through android-based applications such as temperature monitoring, gas intensity, fire identification and automatic monitoring of door conditions. This research aims to design and create a smart home system based on the IoT concept. The research methodology uses an experimental methodology. The design of this system is made using an Android smartphone, Arduino microcontroller, Ethernet shield, relay module, fire sensor, temperature sensor (LM35), gas sensor (MQ6), and magnetic sensor. The results of this study are monitoring and control systems on smart homes by utilizing an already available Web service called Teleduino. This web service functions as an intermediary between an Android device and the Arduino microcontroller. The Arduino Microcontroller requires an additional device called the Ethernet Shield to connect Arduino to the Internet that is connected directly to the Teleduino web service.

\section{PENDAHULUAN}

Rumah dapat berfungsi sebagai tempat untuk menikmati kehidupan yang nyaman, tempat untuk beristirahat, tempat untuk berkumpulnya keluarga dan tempat untuk menunjukkan tingkat sosial dalam masyarakat. Tetapi terkadang fungsi rumah tersebut tidak dapat terus dirasakan senyaman mungkin. Hal ini terjadi karena adanya kekhawatiran pada pemilik rumah yang belum bisa memantau rumahnya secara menyeluruh. Kekhawatiran ini juga terjadi ketika pemilik rumah yang bepergian keluar kota dalam waktu yang cukup lama, sehingga pemilik rumah memiliki kendali dalam pengawasan rumah. Untuk membantu mengatasi permasalahan tersebut diatas beberapa peneliti telah dilakukan.

Pada penelitian [1], membuat sistem kendali peralatan elektronik dengan mikrokontroller raspberry PI sebagai server yang akan menghubungkan antara hardware dan software yang dikontrol melalui web sebagai interface yang dilakukan pengguna untuk memasukan input dan menghasilkan output. Pada penelitian selanjutnya [2] dilakukan pengujian fungsional sistem dengan parameter dapat mengeksekusi perintah dari smartphone android, timer berjalan sesuai waktu masukan dari user dan sensor dapat membaca kondisi lampu dengan benar. Pembuatan sistem smart home [3] yang dapat mengendalikan dan monitoring peralatan elektronik menggunakan komunikasi zigbee untuk pengiriman data ke server dan untuk pengontrolan jarak jauh menggunakan server think speak. Pengembangan dalam sistem smart home berbasis Internet of Things (IoT) [4], dengan pengontrolan lampu dan kipas jarak jauh dengan menggunakan web service untuk kelemahannya belum ada monitoring dari suatu sensor. Pada penelitian sistem saklar pada lampu yang digantikan oleh perangkat relay dengan konektivitas bluetooth [5]. Prototype smart home [6] dengan pengendalian jarak jauh menggunakan mikrokontroller raspberry PI 3, penelitian ini sistem kendali jarak jauh untuk mengontrol peralatan elektronik seperti lampu, kipas angina dan televisi yang dirancang dengan menggunakan LXT terminal pada raspbian dan penelitian ini menggunakan Bahasa pemrograman phyton. Selain itu, pemanfaatan dengan konsep Internet of Things (IoT) pernah digunakan untuk pemantauan aktifitas perawat pada sistem panggilan perawat rumah sakit [7]. Sehingga kualitas pelayanan perawat terhadap pasien dapat terkontrol maksimal.

Berdasarkan penelitian sebelumnya, dapat dianalisis beberapa kelemahan seperti belum dilengkapi kemampuan untuk memontoring suhu, kebocoran gas dan monitoring 
buka tutup pintu. Oleh karena itu pada penelitian ini peneliti mencoba untuk merancang bangun smart home dengan konsep Internet Of Things (IoT) berbasis smartphone yang dapat melengkapi penelitian sebelumnya.

\section{LANDASAN TEORI}

\subsection{Internet Of Things}

Internet of Things (IoT) adalah struktur di mana obyek, orang disediakan dengan identitas eksklusif dan kemampuan untuk pindah data melalui jaringan tanpa memerlukan dua arah antara manusia ke manusia yaitu sumber ke tujuan atau interaksi manusia ke komputer [8]. Internet of Things (IoT) merupakan perkembangan teknologi yang menjanjikan dapat mengoptimalkan kehidupan dengan sensor sensor cerdas dan benda yang memiliki jaringan dan bekerjasama dalam internet.

Internet of Things (IoT) mengacu pada koneksi berbagai perangkat yang menyerupai komputasi tertanam yang dapat terdeteksi seperti sensor pada mobil, implan pemantauan jantung, transponder biochip pada hewan ternak [9]. Ribuan perangkat berinteraksi dengan yang lain melalui komunikasi nirkabel / kabel tanpa campur tangan manusia. Dalam penelitian lain, Internet of Things (IoT) didefinisikan sebagai teknologi baru dengan bantuan perangkat yang dapat berkomunikasi satu sama lain menggunakan sensor [10],[7],[11].

\subsection{Smart Home}

Smart Home adalah aplikasi gabungan antara teknologi dan pelayanan yang dikhususkan pada lingkungan rumah dengan fungsi tertentu yang bertujuan meningkatkan keamanan, efisiensi dan kenyamanan penghuninya. Sistem smart home biasanya terdiri dari perangkat monitoring, perangkat kontrol dan otomatis ada beberapa perangkat yang dapat di akses menggunakan komputer [12][13].

Smart Home merupakan sebuah aplikasi yang dirancang dengan berbantuan komputer yang akan memberikan kenyamanan, keamanan dan penghematan energi yang berlangsung secara otomatis sesuai dengan kendali pengguna dan terprogram melalui komputer pada gedung atau tempat tinggal kita [14]. Teknologi yang dirancangan untuk rumah pintar ini bertujuan untuk memudahkan pemilik rumah dalam memantau kondisi peralatan elektronik yang terhubung dari gadget yang dimiliki.

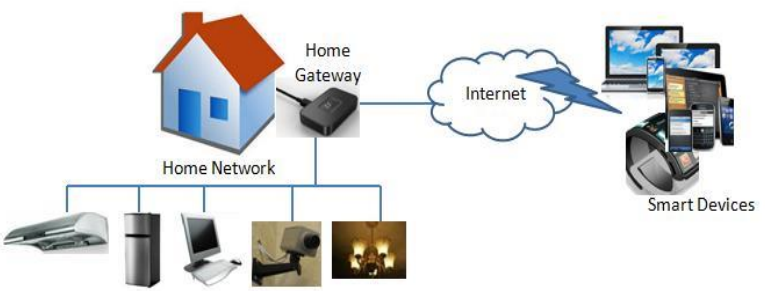

Gambar 1. Arsitektur Sistem Smart Home

\section{METODOLOGI}

Tahapan penelitian terdiri dari empat tahapan dimulai dari analisis sistem, kemudian perancangan prototype smart home, pembuatan program, terakhir implementasi serta pengujian seperti yang dapat dilihat pada gambar 2 .

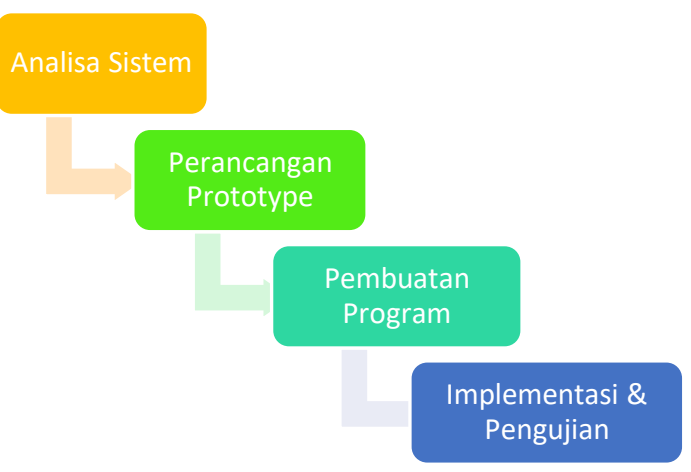

Gambar 2 Metodologi Penelitian

Sistem kontrol dan monitoring yang dikembangkan melibatkan hardware dan software. Sistem dirancang untuk dapat melakukan pengendalian dan monitoring terhadap suatu rumah melalui aplikasi smartphone yang terbubung dengan jaringan internet. Secara umum arsitektur sistem yang dikembangkan ditampilkan pada gambar 3 .

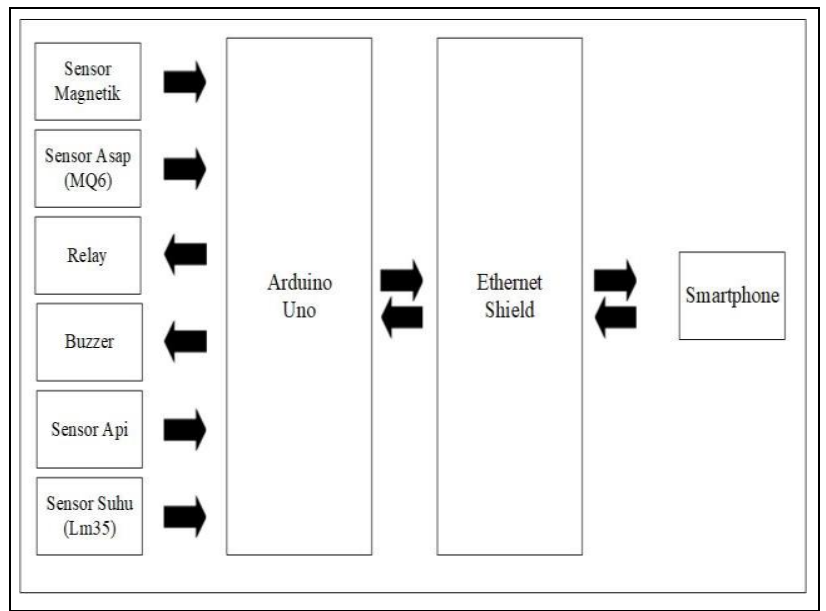

Gambar 3. Blok Diagram

Arsitektur sistem yang dibangun seperti pada gambar 3, melibatkan sembilan komponen hardware utama :

1. Smartphone berfungsi untuk mengontrol dan memonitoring output dan input dari mikrokontroller.

2. Arduino uno berfungsi sebagai sistem yang memanifulasi,mengeksekusi dan memonitor proses kerja alat.

3. Ethernet shield berfungsi sebagai penyambung antara Arduino uno dan internet.

4. Sensor Magnetik berfungsi sebagai sensor magnetic dengan output Boolean.

5. Sensor LM35 berfungsi sebagai pengukur perubahan suhu.

6. Sensor asap MQ6 digunakan untuk mendeteksi kadar asap dan gas.

7. Sensor api digunakan untuk mendeteksi adanya api. 
8. Buzzer digunakan untuk memberikan informasi berupa bunyi.

9. Relay digunakan saklar atau alat untuk menyambung dan memutus arus

Selain dari hardware, juga dibutuhkan software untuk pengembangan aplikasi. Spesifikasi software yang digunakan dalam pengembangan aplikasi ditampilkan pada Tabel I.

TABLE I. SOFTWARE SPECIFICATION

\begin{tabular}{lll}
\hline No & Software & Version \\
\hline 1 & Pritzing & 0.9 \\
\hline 2 & Arduino IDE & 1.8 .9 \\
\hline
\end{tabular}

Tahapan berikutnya membuat rancangan sistem kontrol dan monitoring yang dapat melakukan komunikasi antara mikrokontroller dan aplikasi smart home. Terdapat satu aplikasi utama dan satu web server pada sistem ini yaitu aplikasi smart home dan web server teleduino. Komunikasi antara aplikasi dan mikrokontroller dilakukan dengan cara mengirim (post) di url dan mengambil data (get) di url yang telah disediakan oleh web. Secara umum alur sistem kontrol dan monitoring dijelaskan dalam bentuk flowchart pada gambar 4 .

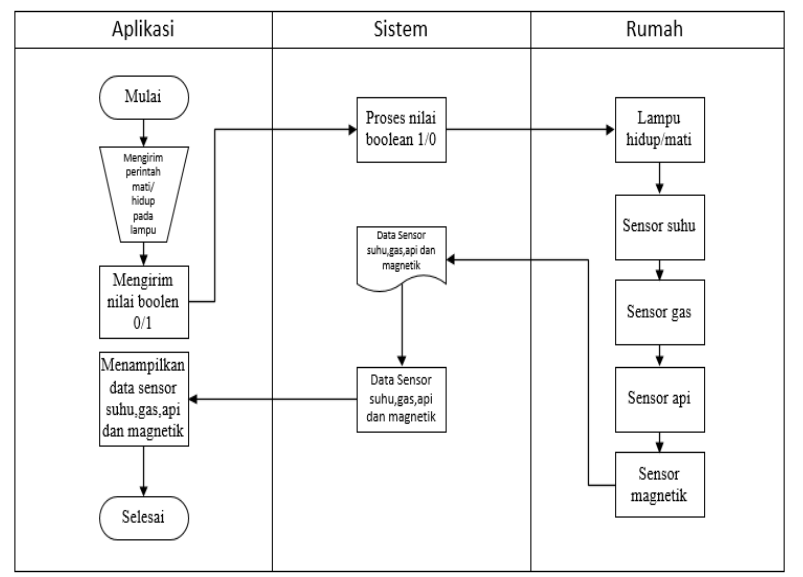

Gambar 4. Flowchart Sistem

Server memeriksa apakah client menerima atau mengirim data, jika berhasil web server akan menampilkan data berupa Json "OK". Jika gagal maka pesan yang ditampilkan "key is offline or invalid".

Setelah rancangan selesai dibuat maka, tahap berikutnya dilakukan implementasi atau pengembagan sistem. Hasil dari aktivias ini menghasilkan dua sistem utama yaitu sistem kendali dan monitoring jarak jauh. Kedua sistem tersebut dirancang untuk tidak memerlukan konfigurasi yang kompleks pada saat penggunaanya. Secara umum tahapan penggunaan aplikasi ditampilkan pada gambar 5 .

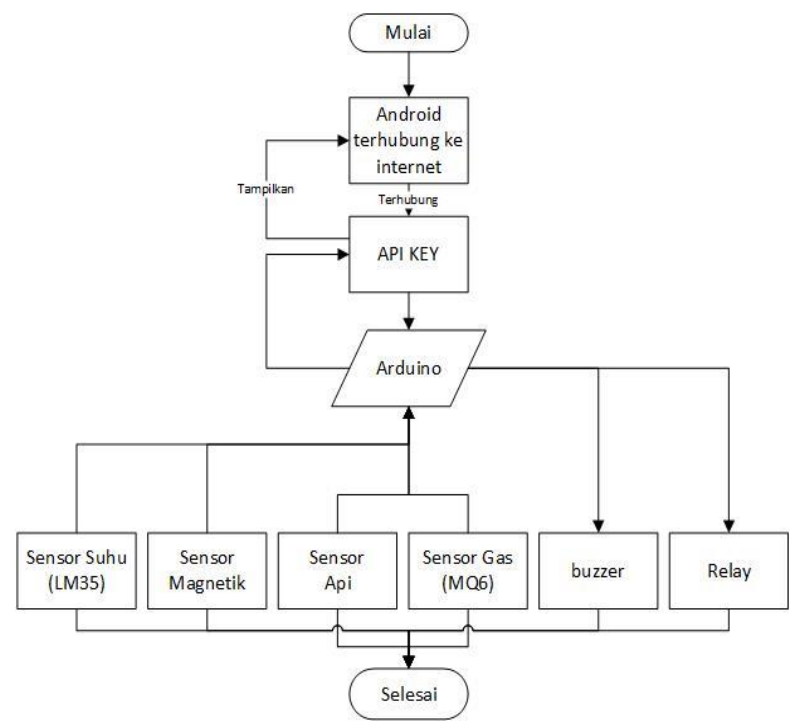

Gambar 5. Diagram Alur Sistem

Pada gambar 5 ditampilkan tahapan penggunaan aplikasi secara umum. Langkah awal pastikan hardware Mikrokontroller dan smartphone sudah terhubung ke internet. Install aplikasi smart home di smartphone yang akan digunakan oleh pengguna. Tahap pertama pengontrolan sistem, jalankan aplikasi smart home yang telah terinstall pilih mode touch control atau mode voice control, kemudian pilih tombol yang akan dilakukan pengontrolan. Tahap berikutnya monitoring jalankan aplikasi smart home yang telah terinstall pilih mode monitoring satu atau monitoring dua lalu akan muncul pembacaan hardware yang dikirim dari mikrokontroller. Jika tidak ada masalah maka komunikasi mikrokontroller dan aplikasi smart home berhasil dibangun dan proses presentasi siap dilakukan.

\section{HASIL DAN ANALISIS}

Terdapat empat tahap utama yang dilakukan pada percobaan dalam penelitian ini yaitu : hardware preparation, network configuration, install and runing smart home app, testing.

\section{A. Hardware preparation}

Pada tahap ini dilakukan identifikasi kebutuhan hardware yang diperlukan pada implementasi sistem kendali dan monitoring smart home. Hardware yang digunakan meliputi arduino uno, Ethernet shield, sensor suhu, sensor gas, sensor magnetik, sensor api, dan smartphone. Selain itu juga dibutuhkan accessinternet untuk menghubungkan Ethernet shield dan jaringan internet. Spesifikasi hardware yang digunakan ditampilkan pada Tabel II.

TABLE II. HARDWARE SPECIFICATION

\begin{tabular}{lll}
\hline No & Item & Description \\
\hline $\mathbf{1}$ & Smartphone & - CPU: Quad-core 1.40 GHz \\
& & Cortex-A53 \\
& & - Memory: 2 GiB \\
& & - OS: Android 7.1.2 (Nougat) \\
& & - Display: 1080 x 1920 pixels \\
\hline $\mathbf{2}$ & Arduino Uno & - CPU: AMD A9-9420 \\
& & Dual Core 3.0 GHz \\
& & - Memory: 4 GiB \\
\hline
\end{tabular}

Ruuhwan 


\begin{tabular}{lll}
\hline & & - OS: Windows 10 \\
& & - Display: 1366 x 768 pixels \\
& & - Connectivity: WiFi \\
\hline $\mathbf{4}$ & Ethernet & - Voltage 5volt (DC) \\
& Shield & - Core chip Wiznet W5100 \\
& & - Koneksi 10/100 mb(fast Ethernet) \\
\hline $\mathbf{5}$ & Sensor Suhu & - Voltage 4(vdc)-30(vdc) \\
& & - sakala 10mv/ \\
& & - Output : analog \\
\hline $\mathbf{6}$ & Sensor Gas & - Voltage 5(vdc) \\
& & - Range 200-10000 ppm \\
& & - Output : analog \\
\hline $\mathbf{7}$ & Sensor api & - Voltage :3,3-9(vdc) \\
& & - Range 700-1100mm \\
& & - Output : digital \\
\hline $\mathbf{8}$ & Sensor & - Rate current : 100(ma) \\
& Magnetik & - Koneksi : Normally Close (NC) \\
& & \\
\hline $\mathbf{9}$ & Buzzer & - Voltage 5(vdc) \\
& &
\end{tabular}

\section{B. Network Configuration}

Pada pengaturan jaringan, tidak ada konfirgurasi spesial yang harus dilakukan. Penggunaan aplikasi dapat digunakan pada jaringan Internet. Percobaan pada penelitian ini dilakukan pada jaringan internet dari ISP provider. Untuk hardware mikrokontroller dikoneksikan menggunakan LAN. Acess point dikonfigurasi sebagai DHCP server, sehingga client mendapatkan IP address secara dinamis dan terhubung pada internet.

\section{Install and runing smart home app}

Pada bagian ini dilakukan instalasi aplikasi smart home pada smartphone pengguna. Tahap awal yang harus dilakukan adalah menjalankan aplikasi pada smartphone yang akan digunakan pengguna dan berfungsi sebagai contoh percobaan. Aplikasi dirancang untuk tidak memerlukan konfigurasi yang kompkleks, sehingga pengguna tidak direpotkan saat penggunakan aplikasi ini.

Setelah aplikasi smart home dijalankan seperti pada Gambar 6, kemudian isi username dan password yang sudah dibuat lalu tekan submit.

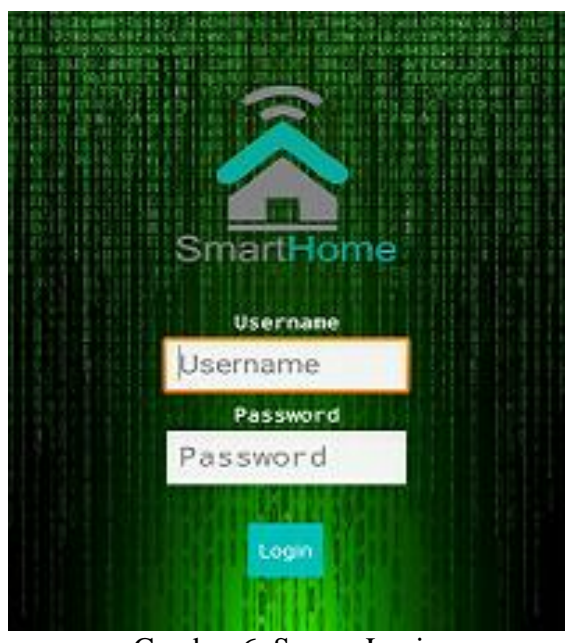

Gambar 6. Screen Login

Tahap percobaan pertama menjalankan aplikasi smart home dengan mode touch control. Pada percobaan aplikasi smart home mode touch control ketika salah satu tombol ditekan maka tombol akan berubah warna menjadi kuning yang menanndakan lampu menyala. Tampilan touch control dapat dilihat pada gambar 7 .

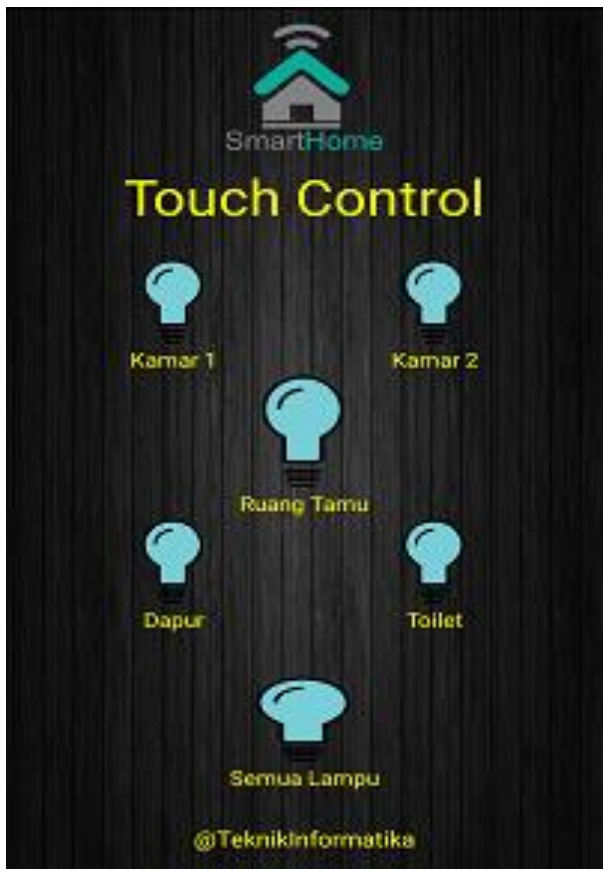

Gambar 7. Tampilan Touch Control

Tahap selanjutnya menjalankan aplikasi smart home dengan mode voice control. Pada percobaan mode touch control, pengujian dilakukan dengan menggunaan suara yang berupa kalimat-kalimat yang telah di tentukan sebelumnya. Seperti pada tampilan gambar 8 .

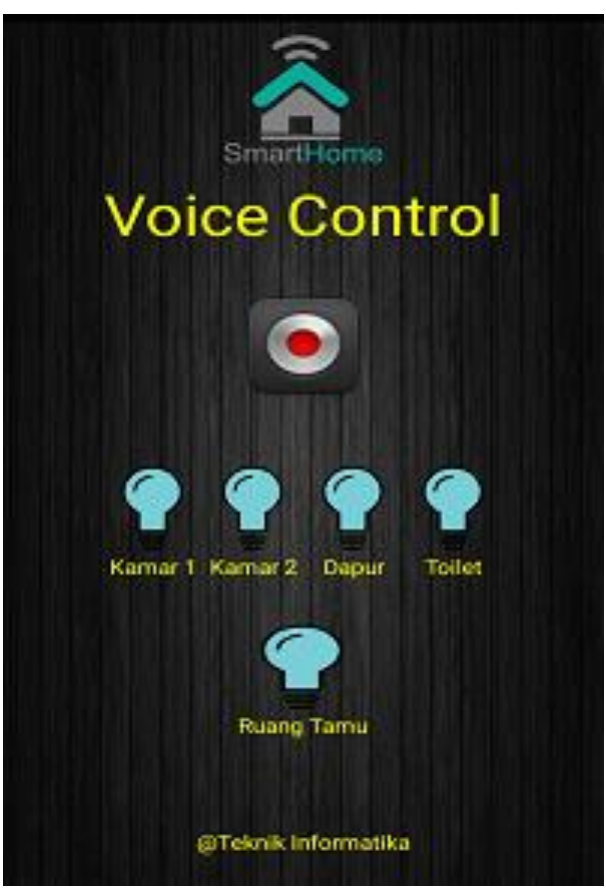

Gambar 8. Tampilan Voice Control

Tahap selanjutnya menjalankan aplikasi smart home dengan fungsi monitoring satu. Pada percobaan aplikasi smart home monitoring satu, aplikasi dapat membaca output dari sistem yang berupa monitoring pintu dan identifiasi kebakaran.seperti pada tampilan gambar 9. 


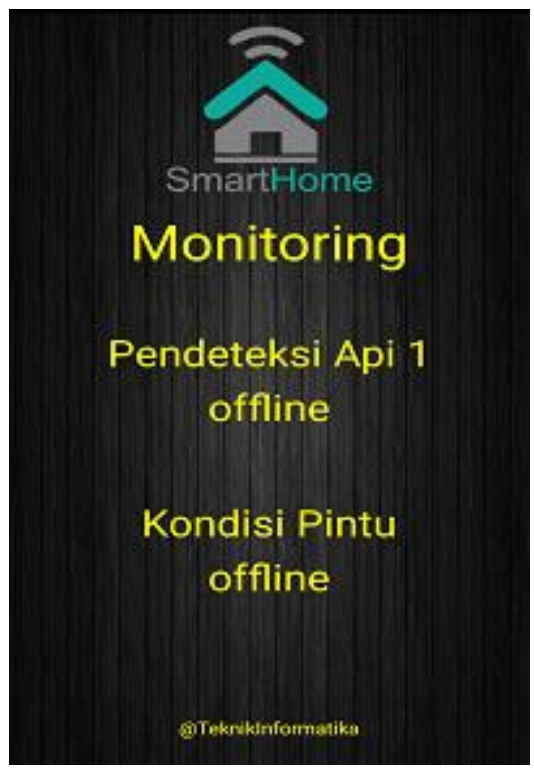

Gambar 9. Tampilan Monitoring Satu

Tahap selanjutnya menjalankan aplikasi smart home dengan fungsi monitoring dua. Pada percobaan aplikasi smart home fungsi monitoring dua, aplikasi dapat membaca output dari sistem yang berupa monitoring intensitas gas dan temperature suhu. Seperti pada tampilan gambar 10.

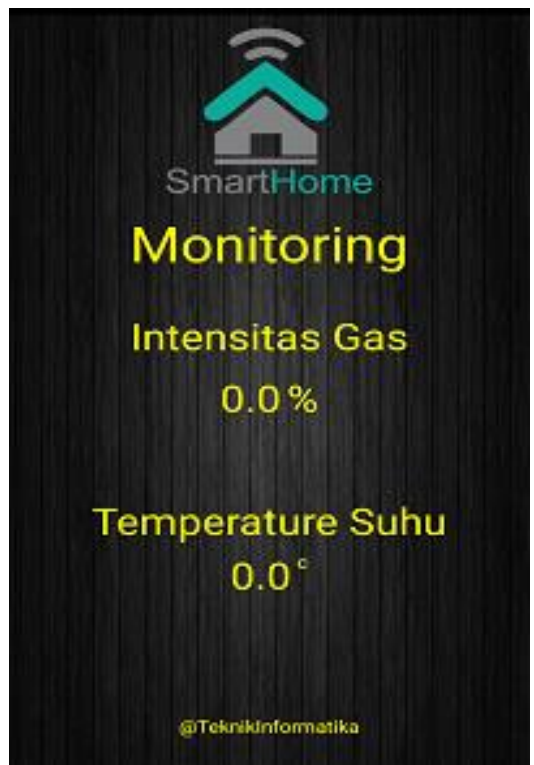

Gambar 10. Tampilan Monitoring Dua

\section{Pengujian}

1. Pengujian Sistem

Setelah aplikasi smart home dijalankan, pada percobaan ini digunakan mode touch control. Tampilan hasil percobaan ditampilkan pada gambar 11 .

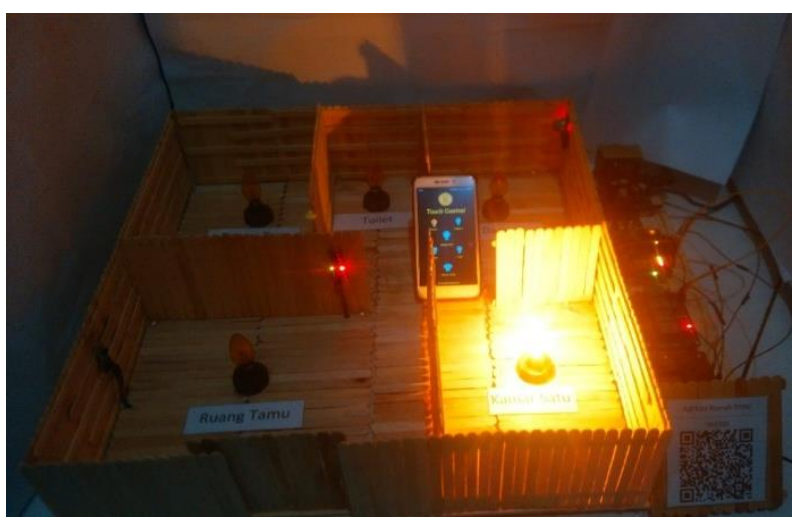

Gambar 11. Tampilan Touch Control

Selanjutnya, percobaan dilakukan dengan mode voice control. Tampilan hasil percobaandapat dilihat pada Gambar 12.

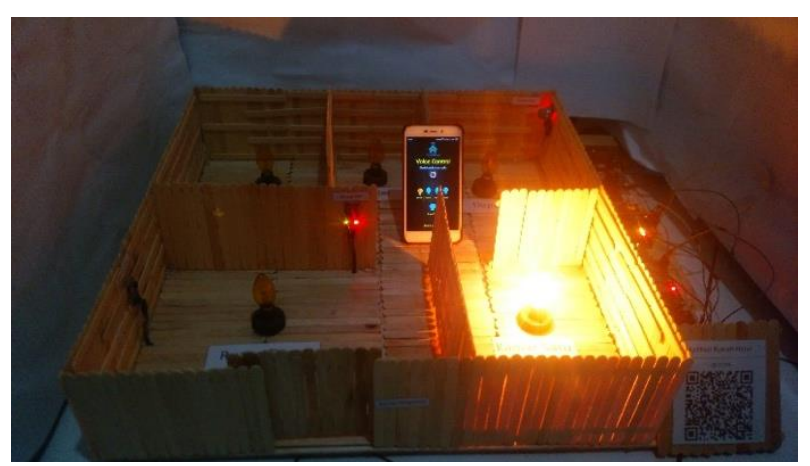

Gambar 12. Tampilan Voice Control

Berikutnya, Percobaan mode monitoring satu. Pada monitoring satu ditampilkan hasil output dua sensor yaitu sensor api dan sensor magnetik. Hasil percobaan monitoring satu, dapat dilihat pada gambar 13 dan 14 .

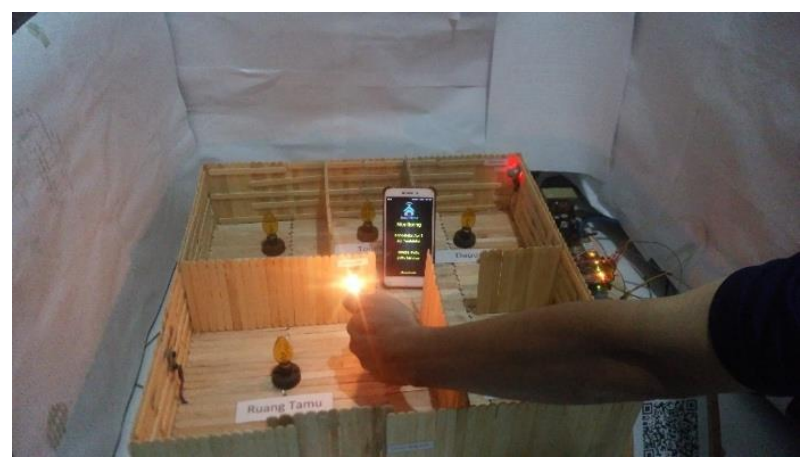

Gambar 13. Tampilan Monitoring Sensor Api

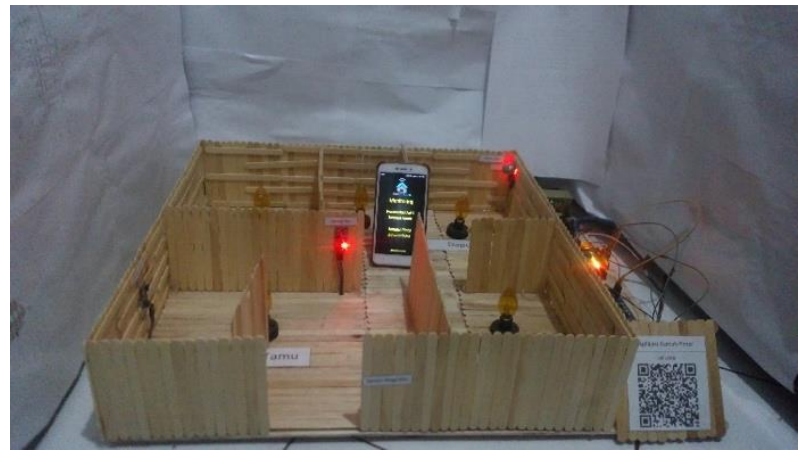

Gambar 14. Tampilan Monitoring Sensor Magnetik 
Berikutnya, Percobaan mode monitoring dua. Pada monitoring dua ditampilkan hasil output dua sensor yaitu sensor suhu dan sensor gas. Hasil percobaan dapat dilihat pada gambar 15.

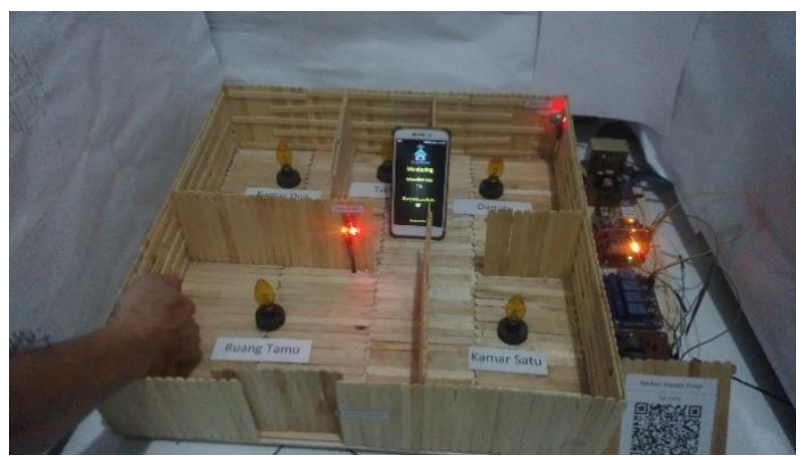

Gambar 15. Tampilan Monitoring Sensor Gas dan Suhu

\section{Hasil Pengujian Sistem}

Pada bagian ini disajikan hasil percobaan sistem control mode touch control, voice control dan mode monitoring satu dan monitoring dua. Seperti yang dapat dilihat pada Table III,.

\begin{tabular}{|c|c|c|c|c|}
\hline & & & & TROL \\
\hline $\begin{array}{c}\text { Per } \\
\text { cobaan }\end{array}$ & $\begin{array}{c}\text { Jenis } \\
\text { Pengujian }\end{array}$ & $\begin{array}{c}\text { Yang } \\
\text { diharapkan }\end{array}$ & $\begin{array}{c}\text { Pengama } \\
\text { tan }\end{array}$ & Hasil \\
\hline 1 & $\begin{array}{l}\text { Lampu ruang } \\
\text { tamu } \\
\text { dinyalakan } \\
\text { dengan mode } \\
\text { touch control }\end{array}$ & $\begin{array}{l}\text { Alat dapat } \\
\text { membaca nilai } \\
\text { Boolean satu } \\
\text { dan relay hidup }\end{array}$ & $\begin{array}{l}\text { Lampu } \\
\text { menyala }\end{array}$ & Diterima \\
\hline 2 & $\begin{array}{l}\text { Lampu kamar } \\
\text { satu } \\
\text { dinyalakan } \\
\text { dengan mode } \\
\text { touch control }\end{array}$ & $\begin{array}{l}\text { Alat dapat } \\
\text { membaca nilai } \\
\text { Boolean satu } \\
\text { dan relay hidup }\end{array}$ & $\begin{array}{l}\text { Lampu } \\
\text { menyala }\end{array}$ & Diterima \\
\hline 3 & $\begin{array}{l}\text { Lampu kamar } \\
\text { dua dinyalakan } \\
\text { dengan mode } \\
\text { touch control }\end{array}$ & $\begin{array}{l}\text { Alat dapat } \\
\text { membaca nilai } \\
\text { Boolean satu } \\
\text { dan relay hidup }\end{array}$ & $\begin{array}{l}\text { Lampu } \\
\text { menyala }\end{array}$ & Diterima \\
\hline 4 & $\begin{array}{l}\text { Lampu dapur } \\
\text { dinyalakan } \\
\text { dengan mode } \\
\text { touch control }\end{array}$ & $\begin{array}{l}\text { Alat dapat } \\
\text { membaca nilai } \\
\text { Boolean satu } \\
\text { dan relay hidup }\end{array}$ & $\begin{array}{l}\text { Lampu } \\
\text { menyala }\end{array}$ & Diterima \\
\hline 5 & $\begin{array}{l}\text { Lampu toilet } \\
\text { dinyalakan } \\
\text { dengan mode } \\
\text { touch control }\end{array}$ & $\begin{array}{l}\text { Alat dapat } \\
\text { membaca nilai } \\
\text { Boolean satu } \\
\text { dan relay hidup }\end{array}$ & $\begin{array}{l}\text { Lampu } \\
\text { menyala }\end{array}$ & Diterima \\
\hline 6 & $\begin{array}{l}\text { Lampu ruang } \\
\text { tamu } \\
\text { dimatikan } \\
\text { dengan mode } \\
\text { touch control }\end{array}$ & $\begin{array}{l}\text { Alat dapat } \\
\text { membaca nilai } \\
\text { Boolean } \\
\text { kosong dan } \\
\text { relay mati }\end{array}$ & $\begin{array}{l}\text { Lampu } \\
\text { mati }\end{array}$ & Diterima \\
\hline 7 & $\begin{array}{l}\text { Lampu kamar } \\
\text { satu dimatikan } \\
\text { dengan mode } \\
\text { touch control }\end{array}$ & $\begin{array}{l}\text { Alat dapat } \\
\text { membaca nilai } \\
\text { Boolean } \\
\text { kosong }\end{array}$ & $\begin{array}{l}\text { Lampu } \\
\text { mati }\end{array}$ & Diterima \\
\hline 8 & $\begin{array}{l}\text { Lampu kamar } \\
\text { dua dimatikan } \\
\text { dengan touch } \\
\text { control }\end{array}$ & $\begin{array}{l}\text { Alat dapat } \\
\text { membaca nilai } \\
\text { Boolean } \\
\text { kosong dan } \\
\text { relay mati }\end{array}$ & $\begin{array}{l}\text { Lampu } \\
\text { mati }\end{array}$ & Diterima \\
\hline 9 & $\begin{array}{l}\text { Lampu dapur } \\
\text { dimatikan } \\
\text { dengan mode } \\
\text { touch control }\end{array}$ & $\begin{array}{l}\text { Alat dapat } \\
\text { membaca nilai } \\
\text { Boolean } \\
\text { kosong dan } \\
\text { relay mati }\end{array}$ & $\begin{array}{l}\text { Lampu } \\
\text { mati }\end{array}$ & Diterima \\
\hline 10 & $\begin{array}{l}\text { Lampu toilet } \\
\text { dimatikan } \\
\text { dengan mode } \\
\text { touch control }\end{array}$ & $\begin{array}{l}\text { Alat dapat } \\
\text { membaca nilai } \\
\text { Boolean } \\
\text { kosong dan } \\
\text { relay mati }\end{array}$ & $\begin{array}{l}\text { Lampu } \\
\text { mati }\end{array}$ & Diterima \\
\hline
\end{tabular}

\begin{tabular}{|c|c|c|c|c|}
\hline 11 & $\begin{array}{l}\text { Semua lampu } \\
\text { dinyalakan } \\
\text { dengan mode } \\
\text { touch control }\end{array}$ & $\begin{array}{l}\text { Alat dapat } \\
\text { membaca nilai } \\
\text { Boolean satu } \\
\text { dan relay hidup } \\
\text { semua }\end{array}$ & $\begin{array}{l}\text { Semua } \\
\text { lampu } \\
\text { menyala }\end{array}$ & Diterima \\
\hline 12 & $\begin{array}{l}\text { Semua lampu } \\
\text { dimatikan } \\
\text { dengan mode } \\
\text { touch control }\end{array}$ & $\begin{array}{l}\text { Alat dapat } \\
\text { membaca nilai } \\
\text { Boolean satu } \\
\text { dan relay mati } \\
\text { semua }\end{array}$ & $\begin{array}{l}\text { Semua } \\
\text { lampu } \\
\text { mati }\end{array}$ & Diterima \\
\hline 13 & $\begin{array}{l}\text { Lampu ruang } \\
\text { tamu } \\
\text { dinyalakan } \\
\text { dengan mode } \\
\text { voice control }\end{array}$ & $\begin{array}{l}\text { Alat dapat } \\
\text { membaca nilai } \\
\text { Boolean satu } \\
\text { dan relay hidup }\end{array}$ & $\begin{array}{l}\text { Lampu } \\
\text { menyala }\end{array}$ & Diterima \\
\hline 14 & $\begin{array}{l}\text { Lampu kamar } \\
\text { satu } \\
\text { dinyalakan } \\
\text { dengan mode } \\
\text { voice control }\end{array}$ & $\begin{array}{l}\text { Alat dapat } \\
\text { membaca nilai } \\
\text { Boolean satu } \\
\text { dan relay hidup }\end{array}$ & $\begin{array}{l}\text { Lampu } \\
\text { menyala }\end{array}$ & Diterima \\
\hline 15 & $\begin{array}{l}\text { Lampu kamar } \\
\text { dua dinyalakan } \\
\text { dengan mode } \\
\text { voice control }\end{array}$ & $\begin{array}{l}\text { Alat dapat } \\
\text { membaca nilai } \\
\text { Boolean satu } \\
\text { dan relay hidup }\end{array}$ & $\begin{array}{l}\text { Lampu } \\
\text { menyala }\end{array}$ & Diterima \\
\hline 16 & $\begin{array}{l}\text { Lampu dapur } \\
\text { dinyalakan } \\
\text { dengan mode } \\
\text { voice control }\end{array}$ & $\begin{array}{l}\text { Alat dapat } \\
\text { membaca nilai } \\
\text { Boolean satu } \\
\text { dan relay hidup }\end{array}$ & $\begin{array}{l}\text { Lampu } \\
\text { menyala }\end{array}$ & Diterima \\
\hline 17 & $\begin{array}{l}\text { Lampu toilet } \\
\text { dinyalakan } \\
\text { dengan mode } \\
\text { voice control }\end{array}$ & $\begin{array}{l}\text { Alat dapat } \\
\text { membaca nilai } \\
\text { Boolean satu } \\
\text { dan relay hidup }\end{array}$ & $\begin{array}{l}\text { Lampu } \\
\text { menyala }\end{array}$ & Diterima \\
\hline 18 & $\begin{array}{l}\text { Lampu ruang } \\
\text { tamu } \\
\text { dimatikan } \\
\text { dengan mode } \\
\text { voice control }\end{array}$ & $\begin{array}{l}\text { Alat dapat } \\
\text { membaca nilai } \\
\text { Boolean } \\
\text { kosong dan } \\
\text { relay mati }\end{array}$ & $\begin{array}{l}\text { Lampu } \\
\text { mati }\end{array}$ & Diterima \\
\hline 19 & $\begin{array}{l}\text { Lampu kamar } \\
\text { satu dimatikan } \\
\text { dengan mode } \\
\text { voice control }\end{array}$ & $\begin{array}{l}\text { Alat dapat } \\
\text { membaca nilai } \\
\text { Boolean } \\
\text { kosong dan } \\
\text { relay mati }\end{array}$ & $\begin{array}{l}\text { Lampu } \\
\text { mati }\end{array}$ & Diterima \\
\hline 20 & $\begin{array}{l}\text { Lampu kamar } \\
\text { dua dimatikan } \\
\text { dengan mode } \\
\text { voice control }\end{array}$ & $\begin{array}{l}\text { Alat dapat } \\
\text { membaca nilai } \\
\text { Boolean } \\
\text { kosong dan } \\
\text { relay mati }\end{array}$ & $\begin{array}{l}\text { Lampu } \\
\text { mati }\end{array}$ & Diterima \\
\hline 21 & $\begin{array}{l}\text { Lampu dapur } \\
\text { dimatikan } \\
\text { dengan mode } \\
\text { voice control }\end{array}$ & $\begin{array}{l}\text { Alat dapat } \\
\text { membaca nilai } \\
\text { Boolean } \\
\text { kosong dan } \\
\text { relay mati }\end{array}$ & $\begin{array}{l}\text { Lampu } \\
\text { mati }\end{array}$ & Diterima \\
\hline 22 & $\begin{array}{l}\text { Lampu toilet } \\
\text { dimatikan } \\
\text { dengan mode } \\
\text { voice control }\end{array}$ & $\begin{array}{l}\text { Alat dapat } \\
\text { membaca nilai } \\
\text { Boolean } \\
\text { kosong dan } \\
\text { relay mati }\end{array}$ & $\begin{array}{l}\text { Lampu } \\
\text { mati }\end{array}$ & Diterima \\
\hline 23 & $\begin{array}{l}\text { Semua lampu } \\
\text { dinyalakan } \\
\text { dengan mode } \\
\text { voice control }\end{array}$ & $\begin{array}{l}\text { Alat dapat } \\
\text { membaca nilai } \\
\text { Boolean satu } \\
\text { dan relay hidup } \\
\text { semua }\end{array}$ & $\begin{array}{l}\text { Semua } \\
\text { lampu } \\
\text { mati }\end{array}$ & Diterima \\
\hline 24 & $\begin{array}{l}\text { Semua lampu } \\
\text { dimatikan } \\
\text { dengan mode } \\
\text { voice control }\end{array}$ & $\begin{array}{lr}\text { Alat dapat } \\
\text { membaca } \\
\text { Boolean } & \\
\text { kodong } & \\
\text { relay } & \text { dan } \\
\text { semua } & \end{array}$ & $\begin{array}{l}\text { Semua } \\
\text { lampu } \\
\text { menyala }\end{array}$ & Diterima \\
\hline
\end{tabular}

TABLE IV. Pengujian SEnsor Suhu

\begin{tabular}{cllll}
\hline Percobaan & $\begin{array}{c}\text { Jenis } \\
\text { Pengujian }\end{array}$ & $\begin{array}{c}\text { Yang } \\
\text { diharapkan }\end{array}$ & Pengamatan & Hasil \\
\hline $\mathbf{1}$ & Tanpa & Alat dapat & Aplikasi & Diterima \\
& dipanaskan & $\begin{array}{l}\text { membaca } \\
\text { suhu } \\
\text { disekitar }\end{array}$ & $\begin{array}{l}\text { dapat } \\
\text { menampilkan } \\
\text { suhu standar }\end{array}$ & \\
\hline $\mathbf{2}$ & Dipanaskan & Alat dapat & Aplikasi & Diterima \\
& & membaca & dapat & \\
& & kenaikan & menampilkan & \\
& & suhu & kenaikan & \\
& & disekitar & suhu & \\
& & & & \\
\end{tabular}


TABLE V. PENGUJian SENSOR Gas

\begin{tabular}{cllll}
\hline Percobaan & $\begin{array}{c}\text { Jenis } \\
\text { Pengujian }\end{array}$ & $\begin{array}{c}\text { Yang } \\
\text { diharapkan }\end{array}$ & Pengamatan & Hasil \\
\hline $\mathbf{1}$ & Tanpa & Alat dapat & Aplikasi & Diterima \\
diberikan & $\begin{array}{l}\text { membaca } \\
\text { intensitas } \\
\text { gas di sekitar }\end{array}$ & $\begin{array}{l}\text { menampilk } \\
\text { an } \\
\text { intensitas } \\
\text { gas standar }\end{array}$ & \\
& & & Aplikasi & Diterima \\
& & Alat dapat & Aat \\
& Diberikan & menampilk & \\
& gas & intensitas & an kenaikan & \\
& & intensitas & \\
& & gas & & \\
& & & &
\end{tabular}

TABLE VI. PENGUJIAN SENSOR API

\begin{tabular}{|c|c|c|c|c|}
\hline Percobaan & $\begin{array}{c}\text { Jenis } \\
\text { Pengujian }\end{array}$ & $\begin{array}{c}\text { Yang } \\
\text { diharapkan }\end{array}$ & Pengamatan & Hasil \\
\hline 1 & $\begin{array}{l}\text { Sensor } \\
\text { Tidak } \\
\text { diberi api }\end{array}$ & $\begin{array}{l}\text { Alat dapat } \\
\text { membaca } \\
\text { "kondisi } \\
\text { aman }\end{array}$ & $\begin{array}{l}\text { Aplikasi } \\
\text { dapat } \\
\text { menampilka } \\
\text { n kondisi } \\
\text { "kondisi } \\
\text { aman" }\end{array}$ & Diterima \\
\hline 2 & $\begin{array}{l}\text { Sensor } \\
\text { diberi api }\end{array}$ & $\begin{array}{l}\text { Alat dapat } \\
\text { membaca } \\
\text { "api } \\
\text { terdeteksi" }\end{array}$ & $\begin{array}{l}\text { Aplikasi } \\
\text { dapat } \\
\text { menampilka } \\
\text { n "api } \\
\text { terdeteksi"" }\end{array}$ & Diterima \\
\hline
\end{tabular}

TABLE VII. PENGUJIAN SENSOR MAgnetIK

\begin{tabular}{cllll}
\hline Percobaan & $\begin{array}{c}\text { Jenis } \\
\text { Pengujian }\end{array}$ & $\begin{array}{c}\text { Yang } \\
\text { diharapkan }\end{array}$ & Pengamatan & Hasil \\
\hline $\mathbf{1}$ & $\begin{array}{l}\text { Sensor } \\
\text { didekatkan } \\
\text { dengan } \\
\text { magnet }\end{array}$ & $\begin{array}{l}\text { Alat dapat } \\
\text { membaca } \\
\text { "pintu } \\
\text { tertutup" }\end{array}$ & $\begin{array}{l}\text { Aplikasi } \\
\text { dapat } \\
\text { menampilkan } \\
\text { kondisi pintu } \\
\text { tertutup }\end{array}$ & Diterima \\
& Sensor & Alat dapat & $\begin{array}{l}\text { Aplikasi } \\
\text { dapat }\end{array}$ & Diterima \\
& dijauhkan \\
dari & $\begin{array}{l}\text { membaca } \\
\text { magnet }\end{array}$ & terbukampilkan & \\
& & $\begin{array}{l}\text { kondisi pintu } \\
\text { terbuka }\end{array}$ & \\
& & & & \\
\end{tabular}

Masalah utama dalam pembuatan sistem ini adalah web server mempunyai batasan menerima data (get) hanya dua data, sehingga perlu adanya pemisahan permintaan data dari web server.

Keunggulan dalam penelitian ini telah mengatasi kekurangan-kekurangan yang terjadi, diantaranya:

a. Media transmisi data jaringan internet sehingga dalam penggunaanya lebih simpel dan lebih mudah.

b. Tidak memerlukan konfigurasi pada aplikasi, karena sudah didesain seefisien mungkin agar dapat dengan mudah digunak

c. Tidak memerlukan koneksi internet yang super cepat tapi hanya memerlukan koneksi yang stabil.

Teknologi Internet Of Things (IoT) yang digunakan pada penelitian ini mampu mendukung komunikasi jarak jauh sehingga kegiatan pengontrolan dan monitoring dapat diakses secara real-time.

\section{KESIMPULAN}

Smart home berbasis Internet of Things (IoT) dengan menggunakan mikrokontroller Arduino, Ethernet shield, modul relay, sensor api, sensor suhu (LM35), sensor gas
(MQ6), dan sensor magnetik mampu dikendalikan dan dimonitor dari jarak jauh menggunakan smartphone android selama terkoneksi dengan internet.

Penelitian ini perlu dilakukan pengembangan pada penggunaan sensor dan input output yang digunakan seperti penambahan kamera cctv untuk memonitoring aktifitas smart home secara menyeluruh.

\section{DAFTAR PUSTAKA}

[1] F. Masykur and F. Prasetiyowati, "Aplikasi Rumah Pintar (Smart Home) Pengendali Peralatan Elektronik Rumah Tangga Berbasis Web,” J. Teknol. Inf. dan Ilmu Komput., vol. 3, no. 1, p. 51, 2016.

[2] A. D. B. Sadewo, E. R. Widasari, and A. Muttaqin, "Perancangan Pengendali Rumah menggunakan Smartphone Android dengan Konektivitas Bluetooth," J. Pengemb. Teknol. Inf. dan Ilmu Komput., vol. 1, no. 5, pp. 415-425, 2017.

[3] F. Z. Rachman, "Smart Home Berbasis Iot," Snitt, pp. 369-374, 2017.

[4] P. Studi, T. Telekomunikasi, J. T. Elektro, and P. N. Sriwijaya, “( 1,2),” vol. 2, no. 2, pp. 157-165, 2018.

[5] A. Microcontroller, "Jurnal Keteknikan dan Sains (JUTEKS) - LPPM UNHAS Vol. 1, No.1, Juni 2018 23,” J. Keteknikan dan Sains, vol. 1, no. 1, pp. 23-31, 2018.

[6] W. Al Qorni, A. Azhar, and E. Yuniarti, "Perancangan Sistem Kontrol Otomatis Berbasis Web Menggunakan Raspberry Pi 3 pada Smarthome," Al-Fiziya J. Mater. Sci. Geophys. Instrum. Theor. Phys., vol. 1, no. 2, pp. 15-24, 2019.

[7] F. M. S. Nursuwars and A. Rahmatulloh, "RFID for nurse activity monitoring in the hospital's nurse call system with Internet of Thing (IoT) concept," IOP Conf. Ser. Mater. Sci. Eng., vol. 550, p. 012025, 2019.

[8] A. Junaidi, "Internet of Things, Sejarah, Teknologi Dan Penerapannya," J. Ilm. Teknol. Inf., vol. I, no. AUGUST 2015, pp. 62-66, 2016.

[9] N. Chen, C. Viho, A. Baire, X. Huang, and J. Zha, "Ensuring Interoperability for the Internet of Things: Experience with CoAP Protocol Testing," Automatika, vol. 54, no. 4, pp. 448-458, 2013.

[10] V. Jain and R. Jain, "The Internet of Things- Where the Web and the Physical world will meet," Int. J. Comput. Sci. Inf. Technol., vol. 6, no. 1, pp. 724-727, 2015.

[11] Herdianto, "Perancangan Smart Home dengan Konsep Internet of Things ( IoT ) Berbasis Smartphone," Ilm. Core It, no. x, p. 1, 2016.

[12] T. F. Yurnama and N. Azman, "Perancangan Software Aplikasi Pervasive Smart Home," Snati, vol. 2009, no. Snati, pp. E2-E5, 2009.

[13] A. P. Baskoro, F., Widodo, A., Firmansyah, R., Nurdiansyah, "Prototype Smarthome Dengan Catatan 
Waktu Saat Membuka Pintu Dan Kontrol Nyala Lampu Berbasis Internet of Things," Indones. J. Electr. Electron. Eng., vol. 02, no. 01, pp. 29-34, 2019.

[14] D. Kurniadi and L. Amelia, "Sistem Kendali Perangkat Elektronik Rumah Berbasis Android dan Arduino," J. Algoritm., vol. 15, no. 2, pp. 1-6, 2018.

\section{BIODATA PENULIS}

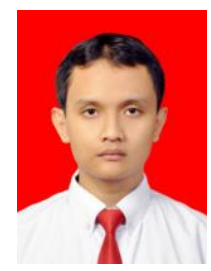

Ruuhwan, S.T., M.Kom. dosen Teknik Informatika, Fakultas Teknik, Universitas Perjuangan, Tasikmalaya, praktisi aktif dalam bidang Keamanan Informasi dan Digital Forensic. Selain sebagai pengajar juga berperan aktif dalam kegiatan Asosiasi Forensik Digital Indonesia (AFDI) dan menjadi direktur di PT. Forensika Digital Nusantara.

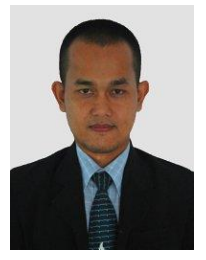

Randi Rizal, S.T., M.Kom. dosen Teknik Informatika, Fakultas Teknik, Universitas Perjuangan, Tasikmalaya, praktisi aktif dalam bidang Internet of Things (IoT), security dan digital forensic. Selain sebagai pengajar juga sebagai CEO Sekolah Programmer yuCoding.com yang merupakan sekolah pemrograman pertama di Tasikmalaya dan sebagai anggota Asosiasi Forensik Digital Indonesia (AFDI).

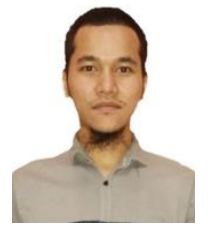

Indra Karyana, saat ini menjadi mahasiswa Teknik Informatika Fakultas Teknik Universitas Perjuangan Tasikmalaya, fokus mendalami bidang Internet of Things (IoT) dan Web

Programming. Selain aktif menjadi mahasiswa, berperan aktif dalam bidang IT di Universitas Perjuangan Tasikmalaya. 